\title{
THE ANALYSIS OF PLANNING AND BUDGETING POLICY FOR MAKING MORE SIGNIFICANT LOCAL GOVERNMENT PLANNING POLICY IN INDONESIA
}

\author{
Rozidateno Putri Hanida ${ }^{1 \star}$, Bimbi Irawan ${ }^{2}$, Syamsurizaldi ${ }^{3}$ \\ ${ }^{1}$ Andalas University, Padang, Indonesia ozidateno@gmail.com \\ 2 BKPM Sumatera Barat Province, Padang, Indonesia bimbiyes@gmail.com \\ ${ }^{3}$ Bappeda Solok Selatan Regency, Padang Aro, Indonesia s.rizaldi@yahoo.co.id \\ ${ }^{*}$ Corresponding Author
}

\begin{abstract}
One of the positive values of the implementation the regional autonomy is local government has the authority to plan and budget for development in its area. The flexibility in preparing documents for planning and budgeting held by local government does not significantly affect the effectiveness regional development planning process. Long process of drafting the planning and budgeting document requires the synchronization of programs and activities of the various documents produced. Analysis to the documents of planning and budgeting in South Solok provide evidence that the programs and activities of development in the region are still not in sync between one policy with others, ranging from the planning document (RKPD) to the budgeting document (KUA-PPAS and APBD).Some programs and activities appear suddenly in the budget documents, while the programs and activities do not exist in the planning documents, and vice versa. Besides inconsistencies of programs and activities in the planning and budgeting documents, there are also a number of problems in these documents, such as the quality of the activities are still low and the activity target that are not measurable. The condition will be worse because of political interference which occurs during the process of drafting, both derived from the chief executive and the legislature. For the future, to make the better development planning, local government must rebuild the organizational structure, the mechanism of action, and coordination in planning agencies. Job description in the division systems of Planning Agencies is often implemented to be a rigid planning. As a result, there is fragmentation, divisions, and selfishness in divisions at planning agencies when they draft planning and budgeting documents. This condition is certainly not helpful to planning process, because however, planning and budgeting process needs integrative, comprehensive, and holistic work.
\end{abstract}

Keywords: Synchronization, Planning, Budgeting, Local government, Planning agency.

\section{INTRODUCTION}

Planning and budgeting process is a step that must be implemented in use of state funds both from the state, provincial, regency/ municipality budget. Within the scope of the regency/ municipality, Local Development Planning Board or can be abbreviated Planning Board (Bappeda) has a strategic role in the implementation process of planning and budgeting in its area. The success of local government in achieving the vision and mission is largely determined by the ability of planning board in dealing with both of these processes. Local planning documents can be categorized into two forms: 1). Document of local development 
planning, such as long term local development planning, and medium term local development planning, and work plan of local government. These documents contain the vision, mission, goals, policies, strategies, programs and, activities; and 2). Document of local financial planning, such as Budget Policy and Platform of Temporary Priority Budget, and Budget Document.

Implementation of planning and budgeting documents is a routine activity undertaken by planning board each year as a translation of the medium and long term planning documents. Every year, each local government must prepare some documents, Work Plan of Local Government or Rencana Kerja Pemerintah Daerah (RKPD), Budget Policy and Platform of Temporary Priority Budget or Kebijakan Umum Anggaran dan Plafon Prioritas Anggaran Sementara (KUA-PPAS), and Budget of Local Income and Expenditure or Anggaran Pendapatan dan Belanja Daerah (APBD) (Figure 1). This paper will analyze the planning and budgeting documents in Solok Selatan Regency in 2011-2013, so that it can be seen how big a role of planning board to keep programs and activities planned to be funded in the budget document that can be implemented in the Fiscal Year.

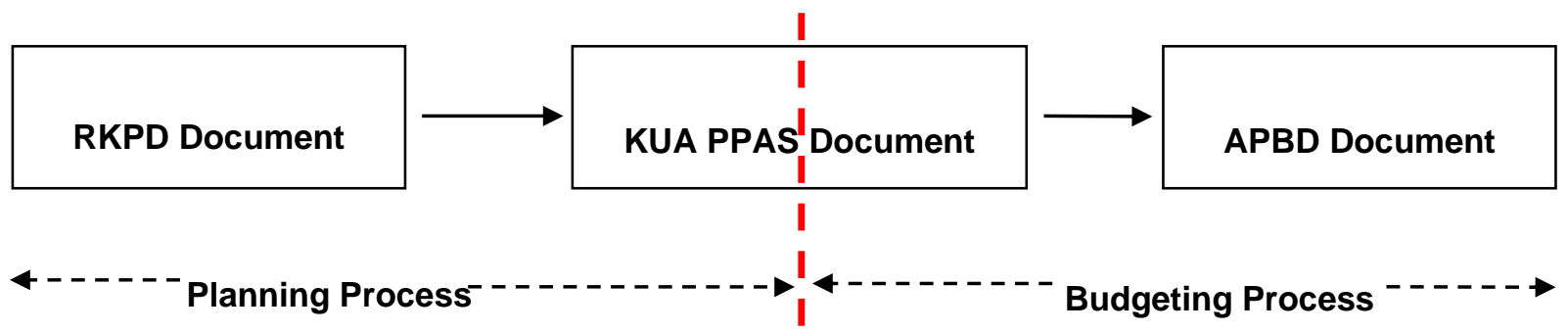

Fig 1: Linkages of planning and budgeting documents

\section{PROCESS OF PLANNING AND BUDGETING IN SOLOK SELATAN REGENCY}

The series of preparation process of planning and budgeting documents has been regulated by the central government with a series of laws and regulations. Each stage has been set the form of the report, the process of document preparation, and also the completion schedule of the process, with expectation that all documents must be completed before the upcoming fiscal year. But in the budget management system, the activities and administration of local government finance is also often less accurate in determining the budget allocated to an activity (Adisasmita, 2011, p.2011).

For 2011 and 2012, the preparation of planning documents was so late that impact the delay in setting the budget documents or APBD. In 2013 there was progress in the preparation of planning documents, but still late in setting the budget document (Table 1). At the very least, the preparation of planning documents that are fully domain of planning board was already performed well. The delay in the determination of budget document of Solok Selatan Regency in 2013 was also due to another factor namely the conflict between Government of Solok Selatan and Parliament of Solok Selatan. The conflict made two versions of budget documents of Solok Selatan Regency (Singgalang, 2013).

Table 1: Stages of Preparation of Planning and Budgeting Documents

\begin{tabular}{|l|l|c|c|c|c|}
\hline \multirow{2}{*}{ Documents } & \multicolumn{4}{|c|}{ rule of law } & \multicolumn{2}{c|}{$\begin{array}{c}\text { completion of document in Solok Selatan } \\
\text { Regency for the fiscal year }\end{array}$} \\
\cline { 2 - 6 } & $\begin{array}{c}\text { pattern of the } \\
\text { legality of } \\
\text { document }\end{array}$ & $\begin{array}{c}\text { deadline for } \\
\text { completion of } \\
\text { document }\end{array}$ & 2011 & 2012 & 2013 \\
\hline RKPD & Regent Regulation & 4-th week in May & $12 / 26 / 2010$ & $09 / 15 / 2011$ & $06 / 12 / 2012$ \\
\hline KUA PPAS & $\begin{array}{l}\text { Memorandum of } \\
\text { Understanding } \\
\text { between Local } \\
\text { Government and } \\
\text { Parliament }\end{array}$ & 4-th week in July & $01 / 05 / 2011$ & $01 / 05 / 2012$ & $09 / 13 / 2012$ \\
\hline
\end{tabular}




\begin{tabular}{|l|l|c|c|c|c|}
\hline APBD & $\begin{array}{l}\text { Local Government } \\
\text { Regulation }\end{array}$ & $\begin{array}{c}\text { no later than November } \\
30\end{array}$ & $03 / 16 / 2011$ & $03 / 07 / 2012$ & $02 / 01 / 2013$ \\
\hline
\end{tabular}

Source: Adapted from various sources of Performance Reports of Government Solok Selatan

\section{SYNCHRONIZATION OF PLANNING AND BUDGET DOCUMENTS}

Programs and activities funded in the budget document should have started from RKPD document. Programs and activities in the planning document (RKPD) will be discussed related to funding. Planning board must guard all programs and activities that always exist in the budgeting documents both KUA-PPAS and APBD (Peraturan Menteri Dalam Negeri/ Regulation of Home Affair Minister of Republic Indonesia No. 54/2010). During the years 2011-2013, there were six cases of non-synchronization forms of planning and budgeting documents, namely:

- $\quad$ Programs and activities only appear in RKPD document.

- $\quad$ Programs and activities only appear in KUA-PPAS document.

- $\quad$ Programs and activities only appear in APBD document.

- $\quad$ Programs and activities only appear in RKPD and KUA-PPAS document.

- $\quad$ Programs and activities only appear in RKPD and APBD document.

- $\quad$ Programs and activities only appear in KUA-PPAS and APBD document.

The six cases show form of irregularities in the preparation of planning and budgeting documents. Logically, a process of an activity must begin listed in RKPD document, then approve in KUA-PPAS document, and funded in budget document or APBD. The appearance of the activities in the budget documents without ever set in the planning documents indicate that these activities are not born of a planning process. The number of programs and activities that are not in sync in planning and budgeting documents can be seen in Table 2 .

Table 2: The number of non-synchronous programs and activities in planning and budgeting documents year 2011-2013

\begin{tabular}{|l|c|c|c|c|c|c|}
\hline \multirow{2}{*}{ Type of case } & \multicolumn{3}{|c|}{ Total Program (P) and activity (A)** are not synchronous in year } \\
\cline { 2 - 7 } & \multicolumn{2}{|c|}{2011} & \multicolumn{2}{c|}{2012} & \multicolumn{2}{c|}{2013} \\
\cline { 2 - 7 } & P & A & P & A & P & A \\
\hline Only appear in RKPD & 54 & 604 & 39 & 417 & 27 & 342 \\
\hline Only appear in KUA-PPAS & 0 & 2 & 0 & 2 & 11 & 102 \\
\hline Only appear in APBD & 1 & 3 & 1 & 11 & 29 & 198 \\
\hline $\begin{array}{l}\text { Only appear in RKPD and } \\
\text { KUA-PPAS }\end{array}$ & 0 & 0 & 0 & 3 & 24 & 176 \\
\hline $\begin{array}{l}\text { Only appear in RKPD and } \\
\text { APBD }\end{array}$ & 0 & 1 & 0 & 0 & 0 & 22 \\
\hline $\begin{array}{l}\text { Only appear in KUA-PPAS } \\
\text { and APBD }\end{array}$ & 83 & 558 & 29 & 290 & 6 & 132 \\
\hline \multicolumn{1}{|c|}{ Total } & $\mathbf{1 3 8}$ & $\mathbf{1 1 6 8}$ & $\mathbf{6 9}$ & $\mathbf{7 2 3}$ & $\mathbf{9 7}$ & $\mathbf{9 7 2}$ \\
\hline
\end{tabular}

Source: Adapted from Rozidateno Putri Hanida research reports (Hanida, 2013)

Notes: * Programs included in this summary is a program that all its activities included in the classification.

** Activities that are included in this summary are all activities included in the classification. 
There are two forms of prominent cases in the year 2011. The first is the number of activities that only appear in RKPD document then lost not followed in subsequent documents. The second case is the programs and activities that appear only in KUA-PPAS and APBD documents, but it is not found in RKPD document. The same trend occurred in 2012. In this case, RKPD document was not become a reference in the preparation of documents further. A big mistake is late determination of KUA-PPAS document, which should be established in July, but could only be set in January next year.

Another case also occurred in 2013. The six types of cases were discovered. But if we observe from the determination of KUA-PPAS document, it is much better than previous years. KUA-PPAS document in 2013 could be set in September 2012, four months ahead of the previous year.

This condition occurred not only for the internal factors in the scope planning board as planners, but also for strongly influenced by external factors. As a planner coordinator, planning board should facilitate the synchronization process of proposed program and activity from all boards in local government (Hanida, 2010). When the discussion of programs and activities in KUA-PPAS document, involvement and intervention of the legislature and the regent are very pronounced, where boards in local government are given new program or activity that never appear in RKPD document, so new program or activity emerge in the budget document or APBD. This condition cannot be called as weak function of planning board, because Regent involvement is very high when the budget discussion. Regent's involvement can be found in the form of intervention to the boards in local government. The basic program and activity that are actually composed by all boards in local government that is written in RKPD document can be lost when budget is discussed. This is caused by high intervention from regent and legislative. This is why programs that suddenly appeared in the budget document is very high.

\section{TARGET OF ACTIVITY}

It is not only the programs and activities that are not consistent, the quality of the proposed activity is also still lacking. One indication that shows the proposed activities is not good can be seen from the target of activities that are not measurable. There are many cases where the activity target is written only 100 percent. The target of 100 percent is not going to provide a strong foundation for planning board and related local government boards in maintaining the existence of these activities, especially in discussions with parliament. The target should be able to give an idea that these activities can be implemented with a maximum amount of budgeted funds.

Table 3: Target of activity in the planning document year 2011-2013

\begin{tabular}{|l|c|c|c|}
\hline \multirow{2}{*}{ Year } & \multicolumn{3}{|c|}{$\begin{array}{c}\text { Activity target in RKPD and } \\
\text { KUA-PPAS document }\end{array}$} \\
\cline { 2 - 4 } & Measurable & $\%$ & Not Measurable \\
\hline 2011 & 421 & 651 & 24 \\
\hline 2012 & 561 & 671 & 32 \\
\hline 2013 & 1083 & 221 & 14 \\
\hline
\end{tabular}

Source: Adapted from Rozidateno Putri Hanida research reports

Table 3 shows that the role of planning board in coordinating the preparation of programs and activities in planning documents shows a fairly good trend from year to year. Next years, planning board need to be more selective in determining the activity target. Target must be set measurable and synchron with the platform of the funds provided. Funds provided should be able to fund these activities in achieving the set targets, so the opportunity to cut the allocation of funds activities can be avoided.

Each proposed program and activity in RKPD and KUA-PPAS documents should be determined explicitly on the output. Target or output will be a performance on any programs and activities organized by each Boards in local government. According to Ihyaul Ulum, it is more difficult to measure output for social services, such as security, education, and health. Efforts that can be done to make programs and activities in the planning documents have a measurable target that can be seen from value for money (Ulum, 20014, p.273). At the 
same time, Legislature should increase its control function, where the legislature should be more serious in checking the target programs and activities in discussing of KUA-PPAS document.

\section{REPETITION OF PROGRAM AND ACTIVITY}

In accordance with the functions possessed by planning board which hold an important role in compiling and synchronize all programs and activities that have been prepared by the boards of local government, it will be easier for planning board to control the programs and activities. They will be effective to make programs and activities without any clear analysis. Repetition of programs and activities and target of activity actually can be a data base and tools for planning board in determining the maximum amount of funds (especially for repetition activities). At the same time, planning board can decide whether these activities need to be repeated or not. Table 4 shows that majority of activities are always repeat every year. Refer to 1,135 activities in 2011, there are 1,249 repeated activities in 2012 and 871 repeated activities in 2013. Two third activities in 2011 were repeated in next years.

Table 4: Number of Repetition Activity on Documents Year 2012-2013

\begin{tabular}{|c|c|c|c|}
\hline \multirow{2}{*}{ Year } & \multicolumn{3}{|c|}{ Activity } \\
\cline { 2 - 4 } & Repetition & Not Repetition & Total \\
\hline 2011 & - & - & 1135 \\
\hline 2012 & 926 & 331 & 1249 \\
\hline 2013 & 871 & 385 & 1255 \\
\hline
\end{tabular}

Source: Adapted from Rozidateno Putri Hanida research reports

Note: Repetitiveness of activities refer to activities in 2011

\section{INTERNAL AND EXTERNAL COORDINATION FUNCTION OF PLANNING BOARD IN THE PREPARATION OF PLANNING AND BUDGETING DOCUMENT}

For further study, there are several root causes of the problem which have weak coordination. In this case, the coordination problem is analyzed into the problems of internal coordination and external coordination (Handoko, 2003). Internal coordination involves work coordination between departments in organization structure of planning board, both horizontally (between sections) and vertically (between leaders and subordinates). On the other hand, external coordination covers all activities and coordination with other boards in local government, the parties to become partners in local development planning (parliament, businesses, NGOs, and universities). In fact, the quality of internal coordination will affect the quality of external coordination, and vice versa. In the internal sphere of planning board, weak coordination caused by:

1. Unclear division of tasks (job division),

2. The lack of clear standard operating procedures that regulate the internal working relationships among the sections of organization,

3. No distribution of right person in each position (the right man in the right place), and

4. Lack of commitment of staff because lack of leadership of the coordinator of local financial management (the Regency Secretary).

5. Furthermore, no distribution of right person in every position is caused by: (a) lack of competent human resources, and (b) the lack of human resources development policy and career path system. Human resource development policy is very political and has no clear standard. Therefore, this condition make inability of planning board of Solok Selatan Regency to run standard operating procedures that were established in the Regulation of Minister of Home Affairs No. 54 of 2010 which had set the preparation of planning documents.

One thing that cannot be denied that also provide considerable influence in the preparation of planning and budgeting documents is a political intervention from the leadership both executive and legislative. This factors is the external factor that are outside the system of planning board as an element of planners, but they have significant influence on the function of coordinating the Planning Agency. Based on this study, this 
factor gives dominant contribution to make the discrepancies between the planning and budgeting documents.

If we look at how the process of the birth of a budget document or APBD, then we can also see how far and where political intervention came and is performed. Before become a budget document or APBD, RKPD document must be a reference for the Local Government Budget Team with the members such as the regency secretary, local financial management board, and planning board in preparing KUA-PPAS document. KUA-PPAS document that was compiled is submitted to the Regent and subsequent Regent submit to parliament to be discussed and agreed upon. Furthermore, KUA-PPAS document that has agreed be a guide in the preparation of the budget documents or APBD.

The intervention of the planning documents has the opportunity during the preparation of KUA-PPAS document. At the time of the preparation of KUA-PPAS document can occur pull of interests each other, so many programs and activities in RKPD document will lose/ disappear? Similarly in the discussion of KUAPPAS and APBD documents, it will make many addition-reduction programs and activities. It also occurs bargaining position of some political interests involved. Therefore, planning board in its capacity to represent Local Government Budget Team, since the beginning of the preparation must do intensive consultation with the Regent. At the same time, planning board must observe and examine the thoughts of parliament that are collected through recess.

In the end, we refer to the local development planning in Indonesia using some approaches. The first is a technocratic approach, where local development planning use methods and scientific framework to achieve the goals and objectives based on physical evidence, data and information that is accurate, and can be accounted for. The second approach, which the participatory development planning carried out the involvement of all stakeholders. The third approach is a political approach whereby development programs is offered by regent that is arranged in medium term local development planning design. And lastly, top-down and bottom-up approach which results in local development planning based on deliberation conducted from village, district, regency, provincial and national levels so as to create synchronization and synergy in achievement of the objectives of national and local development plans.

Solok Selatan Regency Planning Board as the sector leading in the planning area should improve coordination function by improving the quality of internal organization. Planning board must make and use tools that can be used to synergize and synchronize the programs and the activities between both planning and budgeting documents. With these tools, the proposed programs and activities mainly from boards in local government can be controlled and directed to be made based on the performance, so that the proposed programs and activities that are in planning and budgeting documents is a proposal that actually have solid foundation, inputs, outputs, and outcomes. With these conditions, planning board has a strong foundation in maintaining the programs and activities that have been proposed.

\section{CONCLUSION}

To establish synchronization of programs and activities in the preparation of planning and budgeting documents that is undertaken by planning board, it need to give special attention to the organizational structure at local government level, especially in planning board. Another aspect that requires structuring is the mechanism of action and coordination in planning board, both internally and externally.

Recognized or not, one of the weakness points in the organizational structure of planning board of Solok Selatan Regency is the mechanism of action and coordination between sections in planning board that is not optimal. Sections in the organizational structure of planning board of Solok Selatan Regency tend to work in accordance with their respective duties, without feeling the need to find a task or coordinate with other sections. Job descriptions are often interpreted and implemented in a rigidity and full bulkhead. As a result, there is fragmentation, divisions, and selfishness in the body of planning board. This condition is certainly not very conducive to job planning. Because, however, the work plan is a work that is integrative, comprehensive, and holistic.

To ensure relevance and consistency between planning and budgeting need to pay attention to the following:

a. Programs and activities in RKPD document must be the main reference in the preparation of a subsequent documents, to avoid loss of programs and activities in the planning documents or the emergence of new programs and activities in the budget documents.

b. Output or target for each activity in the planning process should be clear and measurable 
c. Planning board that have function as planning agencies must correct the more thoroughly programs and activities that appear repeatedly in every fiscal year.

d. Planning board must improve the functioning of the internal and external coordination in guarding the program and activity that have been planned in the planning documents.

e. Parliament and local government must understand that the escort and consistency of the results of the priority planning activity are needed to make synchronization of planning and budgeting documents.

\section{REFERENCE LIST}

Adisasmita, Rahardjo. (2011). Pengelolaan Pendapatan dan Anggaran Daerah (Management of Local Government Budget dan Income). Yogyakarta: Graha Ilmu.

Handoko, T. Hani. (2003). Manajemen, Edisi Kedua Cetakan ke-18 (Management, Second Edition Volume18). Yogyakarta: BPFE-Yogyakarta.

Hanida, Rozidateno Putri. (2010). Dinamika Penyusunan Anggaran Daerah (Kasus: Proses Penetapan Program dan Alokasi Anggaran Belanja Daerah Di Kabupaten Sleman). (Dynamics of Local Government Budget Preparation (Case: Setting Process of Program and Allocation in Budget of Local Income and Expenditure at Sleman Regency)). Jurnal Penelitian Politik Tahun. 7 (1).

Hanida, Rozidateno Putri, et al. (2013). Laporan Penelitian Analisis Program dan Kegiatan Dalam Dokumen Perencanaan dan Belanja Daerah Guna Meningkatkan Fungsi Koordinasi Dalam Proses Perencanaan Pembangunan (Research Report of Analysis of Program and Activity in Planning and Budgeting Documents for Improving the Coordination Function in Development Planning Process). Bappeda Kabupaten Solok Selatan.

Peraturan Menteri Dalam Negeri (Permendagri) Nomor 54 Tahun 2010 Tentang Tentang Pelaksanaan Peraturan Pemerintah Nomor 8 Tahun 2008 Tentang Tentang Tahapan Tatacara Penyusunan, Pengendalian, Dan Evaluasi Pelaksanaan Pembangunan Daerah (Regulation of Home Affair Minister of Repulic Indonesia No. 54 Year 2010 about Implementation of Government Regulation No. 8 Year 2008 about Procedure Stage of Preparation, Controlling, and Evaluation of Local Government Development Implementation).

Singgalang, Koran Harian. (9 Januari 2013). APBD Solsel Dibahas Kemendagri (Budget Document of Solok Selatan Regency discussed by Home Affair Ministry of Republic Indonesia).

Ulum, Ihyaul. (2004). Akuntasi Sektor Publik, Sebuah Pengantar (Public Sector Accounting, an Introduction). Malang: UMM Press. 